\title{
Early Miocene age of the Stare Bystre Formation based on calcareous nannofossils (Magura Nappe, Outer Carpathians, Poland)
}

\author{
Agata KACZMAREK $^{1, *}$, Marta OSZCZYPKO-CLOWES ${ }^{1}$ and Marek CIESZKOWSKI ${ }^{1}$ \\ 1 Jagiellonian University, Institute of Geological Science, Oleandry 2a, 30-063 Kraków, Poland
}

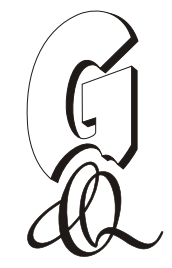

\begin{abstract}
Kaczmarek, A., Oszczypko-Clowes, M., Cieszkowski, M., 2016. Early Miocene age of the Stare Bystre Formation based on calcareous nannofossils (Magura Nappe, Outer Carpathians, Poland). Geological Quarterly, 60 (2): 341-354, doi: 10.7306/gq. 1277

The area of investigation is situated close to the contact zone between the Pieniny Klippen Belt, Krynica Subunit of the Magura Nappe and the Neogene strata of the Orava-Nowy Targ Intramontane Basin (southern Poland). In the area studied, marine deposits of the Stare Bystre Formation outcrop at the surface where they emerge from beneath freshwater and terrestrial Neogene and Quaternary deposits. Nannofossil assemblages from all samples are strongly dominated by reworked species. The Early Miocene age (NN2) of the Stare Bystre Formation has been determined on the base of the first occurrence of Sphenolithus disbelemnos after Shackleton et al. (2000). During the Late Oligocene (NP25/NN1), the frontal part of Magura Nappe was thrust northwards on to the terminal Krosno flysch basin. The northwards thrusting of the Magura Nappe was accompanied by the formation of the piggy-back basin on the Magura Nappe, filled with the synrorogenic turbidites belonging to the Zawada, Kremná and Stare Bystre formations (NN2).
\end{abstract}

Key words: Outer Carpathians, Magura Nappe, Stare Bystre Formation, nannofossils, biostratigraphy, reworking.

\section{INTRODUCTION}

The youngest deposits of the Magura Nappe in Podhale have long attracted interest and controversy (Cieszkowski and Olszewska, 1986; Birkenmajer and Dudziak, 1988; Cieszkowski, 1992; Gedl, 1995) as the dating of the youngest deposits from the Magura Nappe is important both for understanding the tectonics of the Outer Carpathians and for the interpretation of the final evolution of the Central Carpathians and the Pieniny Klippen Belt. The presence of Oligocene/Miocene deposits was confirmed not only in the peri- Pieniny Klippen Belt in Poland and Slovakia, but also in the more external facies zones of the Magura Nappe in Poland (Oszczypko, 1999, 2006; Oszczypko and Oszczypko-Clowes, 2002, 2010b, 2014; Oszczypko et al., 2005a).

In the peri- Pieniny Klippen Belt in Poland and Slovakia and also in the Rača facies zone, the age of the youngest depostis from the Magura Nappe, determined on the basis of calcareous nannoplankton and planktonic foraminifers, is not older than Early Burdigalian and not younger than Late Burdigalian (Oszczypko, 1999, 2006; Oszczypko and Oszczypko-Clowes, 2002, 2010b, 2014; Oszczypko et al., 2005a). The exceptions are outcrops around Waksmund, Zaskale and Stare Bystre (margins of the Orava-Nowy Targ Basin) where, in addition to

\footnotetext{
* Corresponding author, e-mail: agata.kaczmarek@uj.edu.pl
}

Received: September 8, 2015; accepted: December 31, 2015; first published online: February 12, 2016 the Lower Miocene, Middle Badenian and Sarmatian deposits were also initially documented (Cieszkowski et al., 1991; Cieszkowski, 1992). In subsequent papers Cieszkowski (1995) and Cieszkowski and Struska (2009) linked the question of the youngest deposits from the Magura Nappe with the debatable presence of marine Middle Miocene deposits in the Orava-Nowy Targ Intramontane Basin, without additional biostratigraphic data. All these papers described and discussed the section exposed at Stare Bystre (sometimes under the name of Rogoźnik), first described by Watycha (1976) as the Turbacz beds of Paleocene-Early Eocene age.

The aim of our study was to consider the age of the deposits from the Stare Bystre section on the basis of analysis of calcareous nannofossil assemblages.

\section{GEOLOGICAL SETTING}

The Orava-Nowy Targ Basin is an intramontane depression located at the boundary between the Inner and Outer Carpathians, filled with terrestrial and freshwater deposits of Neogene and Quaternary age (Watycha, 1976; Łoziński et al., 2015 with references therein; Fig. 1A). It overlies three older units: the Magura Nappe, the Pieniny Klippen Belt (PKB), and the Podhale sector of the Central Carpathian Paleogene Basin (Fig. 1B).

The Magura Nappe, the largest unit of the Outer Western Carpathians (Fig. 1B), is mainly composed of Upper Cretaceous to Eocene strata. The oldest Lower Cretaceous rocks are known from the peri-PKB area in Poland and from a few localities in Southern Moravia. On the base of facies variations with 


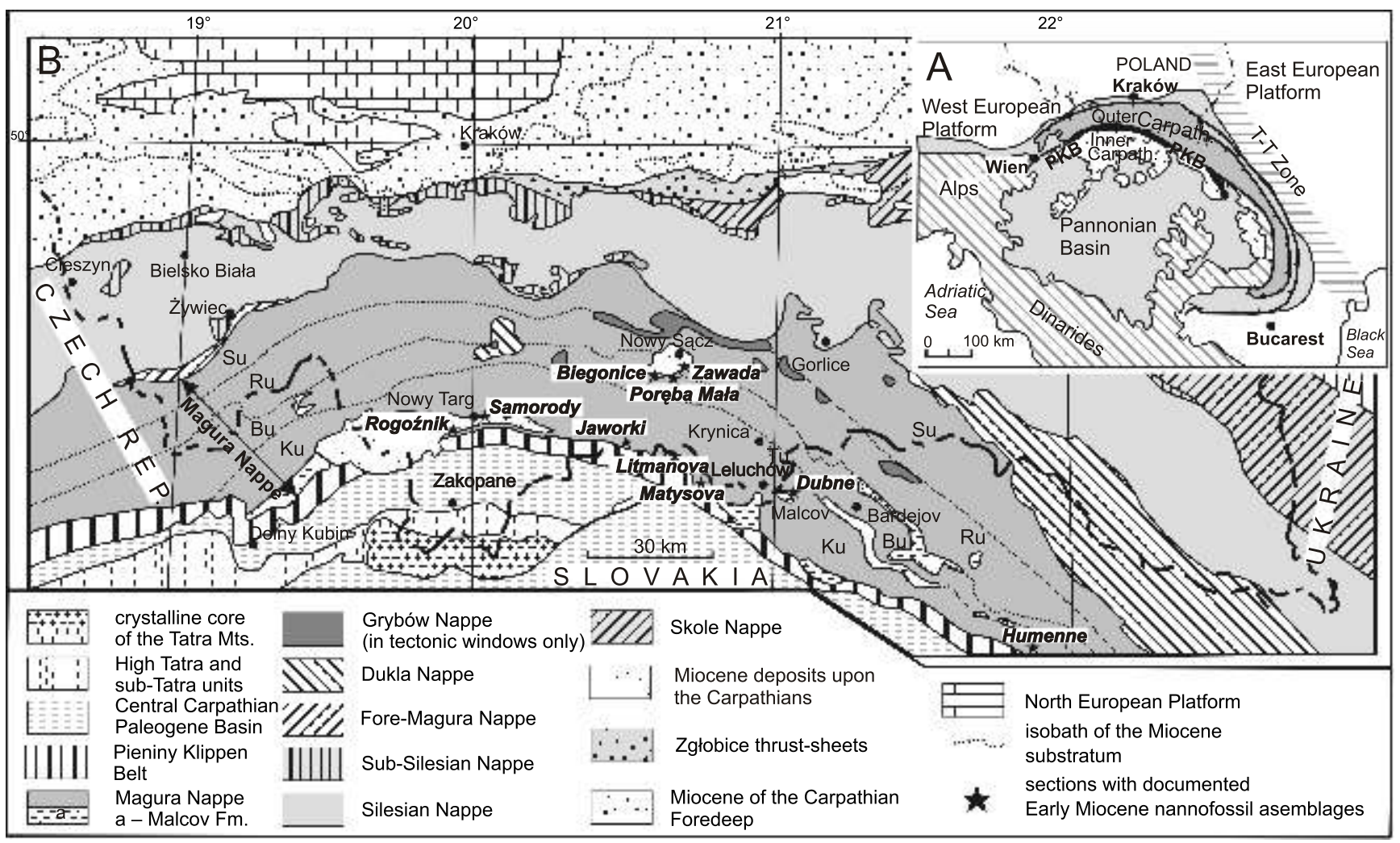

Fig. 1A - geological map of the East Alpine-Carpathian-Pannonian basin system (after Picha and Peters, 1998); B - sketch-map of the Polish Carpathians and their foredeep (based on ytko et al., 1989, supplemented)

$\mathrm{Su}$ - Siary, Ru - Rača, Bu - Bystrica, Ku - Krynica facies zones of the Magura Nappe; place of investigation: black star with the name Rogoźnik on the map

regards to the Paleogene deposits, the Magura Nappe has been subdivided into four facies - tectonic zones namely: the Krynica (Orava), Bystrica (Nowy Sącz), Rača and Siary zones (Fig. 1; see also Koszarski et al., 1974). In the Polish sector of the Magura Nappe (Fig. 1) the youngest deposits have been first documented as the Oligocene Malcov Formation from the Nowy Sącz area (Oszczypko, 1973; see also Oszczypko et al., 1999; Oszczypko and Oszczypko-Clowes, 2002). The same deposits were found in the area near Nowy Targ (Cieszkowsk and Olszewska, 1986; Cieszkowski, 1992), and subsequently, the Kremna Formation (Oligocene-Early Miocene) in the Beskid Sądecki Range and the L'ubovnianska Vrchovina Mts. (Oszczypko-Clowes, 2001, 2012; Oszczypko et al., 2005a; Oszczypko and Oszczypko-Clowes, 2010b), as well as near Humenné (Matašovsky and Andreyeva-Grigorovich, 2002) and Horna Orava (Oszczypko-Clowes et al., 2013) in Slovakia.

The Krynica facies Zone provides important insights as regards our understanding of the terminal history of the Magura Basin formation. This zone records facies links with post-nappe, Late Eocene to Oligocene basins of the Central Carpathians: the Paleogene Basin and the PKB structure Zone (Fig. 2). In the southern part of the Krynica Zone, the youngest deposits belong to the Kremna Formation, established by Oszczypko et al. (2005a). The Kremna Formation (Oszczypko et al., 2005a; Oszczypko and Oszczypko-Clowes, 2010a) is composed of a succession of thin- to medium-bedded turbidites with intercalations of thick-bedded massive sandstone. The upper part is dominated by thin-bedded turbidites. Locally the cal- careous flysch of the Kremna Formation is intercalated with grey marls of Łacko type. The age of the Kremna Formation is Early Miocene, NN2 Zone (Oszczypko et al., 2005a; Oszczypko and Oszczypko-Clowes, 2010b; Fig. 2).

\section{PREVIOUS WORK}

The first reports of the Middle Miocene marine deposits (clays with gypsum) in the Podhale region was given at the end of the nineteenth century by Uhlig (1890). Few years later Friedberg $(1906,1912)$ described marine deposits of Middle Miocene age near Szaflary. This view was questioned by Birkenmajer (1951) who claimed that the finding of Middle Miocene strata in Szaflary by Friedberg $(1906,1912)$ was a result of confusion between samples. At the same time, geological and palynological research in the Orava Basin confirmed the freshwater character and Mio/Pliocene age of these deposits (Foetterle, 1851; Raciborski, 1892; Halicki, 1930; Szafer, 1946-1947; Birkenmajer, 1954, 1958; Szafer and Oszast, 1964; Oszast, 1970; Watycha, 1976, 1977). For the first time in the Magura Nappe, Oligocene deposits (Malcov Formation) were discovered in the Nowy Sacz Basin (Rača Zone), overlying the Magura sandstones (Oszczypko, 1973). Similar deposits were also documented by Cieszkowski and Olszewska (1986) near Nowy Targ. A few years later, with reference to the views of Friedberg (1906, 1920), Cieszkowski et al. (1991) sig- 


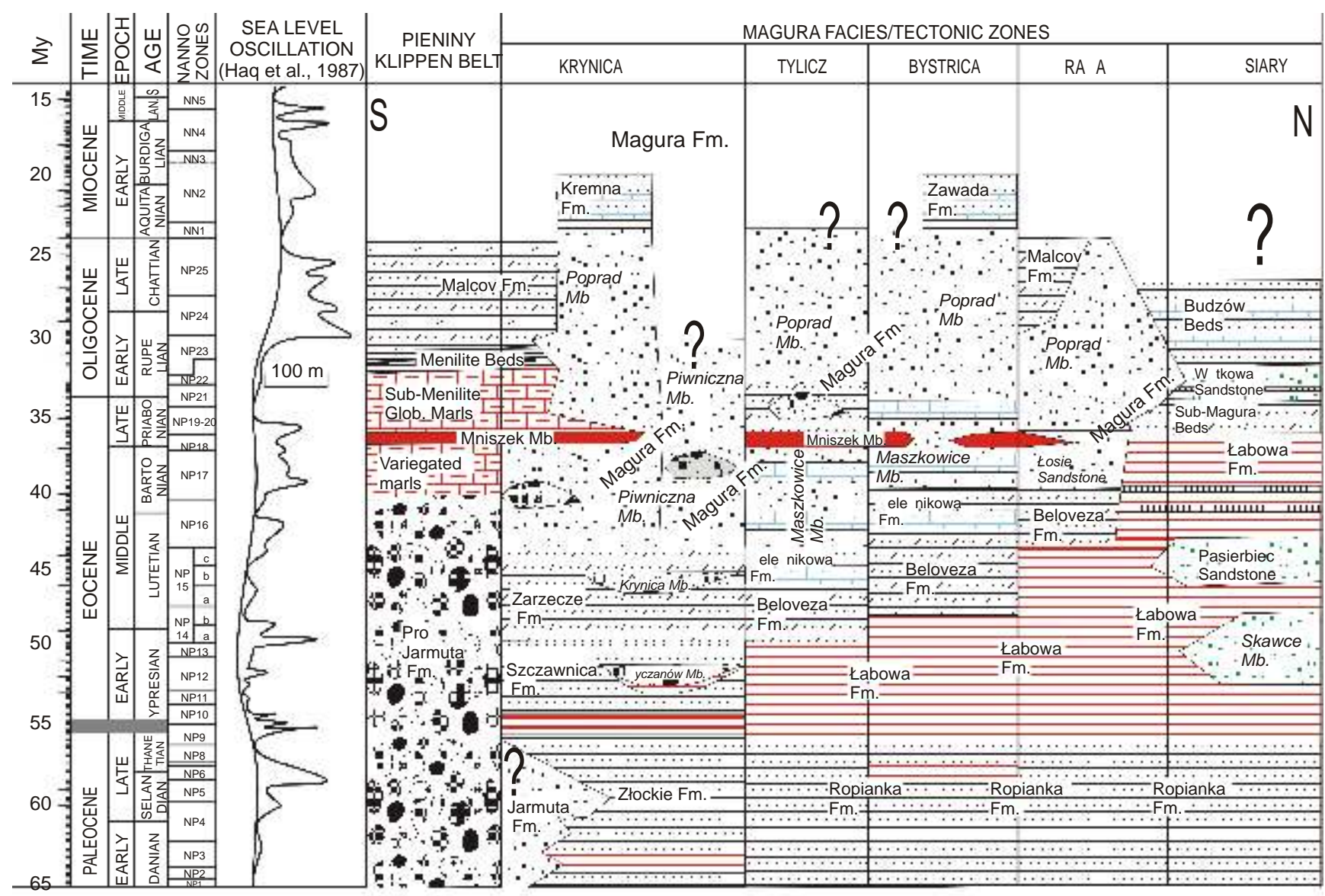

PELAGITES AND HEMIPELAGITES

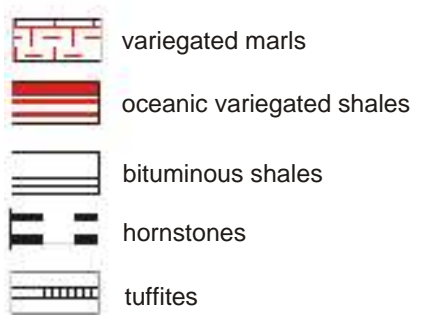

TURBIDITIES

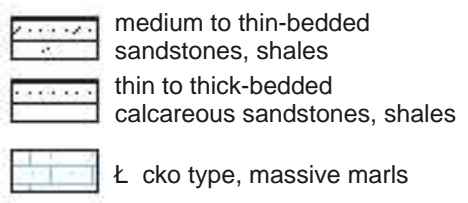

Fig. 2. Lithostratigraphic table of the Paleogene/Early Miocene deposits of the Magura Nappe and Pieniny Klippen Belt (after Oszczypko and Oszczypko-Clowes, 2009)

LAN. - Langhian; S - Serravallian

nalled the possibility of the existence of Middle Miocene marine deposits in the Orava-Nowy Targ Basin. Finally Cieszkowski (1992, 1995) distinguished four new lithostratigraphic units: the Waksmund, Stare Bystre, Kopaczyska and Pasieka units, younger than the Magura and Malcov formations.

The data obtained from the Nowy Targ PIG 1 borehole allowed determination of the age of the Malcov Formation, based on calcareous nannoplankton (Smagowicz in Paul and Poprawa, 1992) ranging from Late Eocene to Early Miocene age. According to Cieszkowski (1992), these beds (in the Orava-Nowy Targ Basin) do not belong to the Malcov Formation but to the deposits which are younger than the Malcov Formation, and named the Waksmund Beds.

The Waksmund Beds seem to form a transitional sequence between the Malcov Formation (Cieszkowski and Olszewska, 1986) and the Miocene beds lying above. The stratigraphic po- sition of these deposits was determined on the basis of their structural context, lithological analogy to the Malcov and/or Magura formations, as well as on micropalaeontological dating. The Waksmund Beds contain foraminifers of a wide stratigraphic range, representing mainly Paleogene or Eocene species (Cieszkowski, 1992). However, the nannoplankton assemblages are abundant, characterized by the presence of: Sphenolithus conicus, Sph. heteromorphus, Sph. pseudoradians and Helicosphaera cf. ampliaperta, and allowed an age determination ....as the Upper Oligocene-Lower Miocene... (Cieszkowski, 1992). Cieszkowski and Struska (2009) included the Waskmund Beds in the Malcov Formation.

The Stare Bystre Formation, developed in flysch facies, is represented by soft marls and marly shales intercalated with thin and medium-bedded calcareous sandstones (Fig. 3C-E). The deposits, which contain rich microfaunal assemblages, 

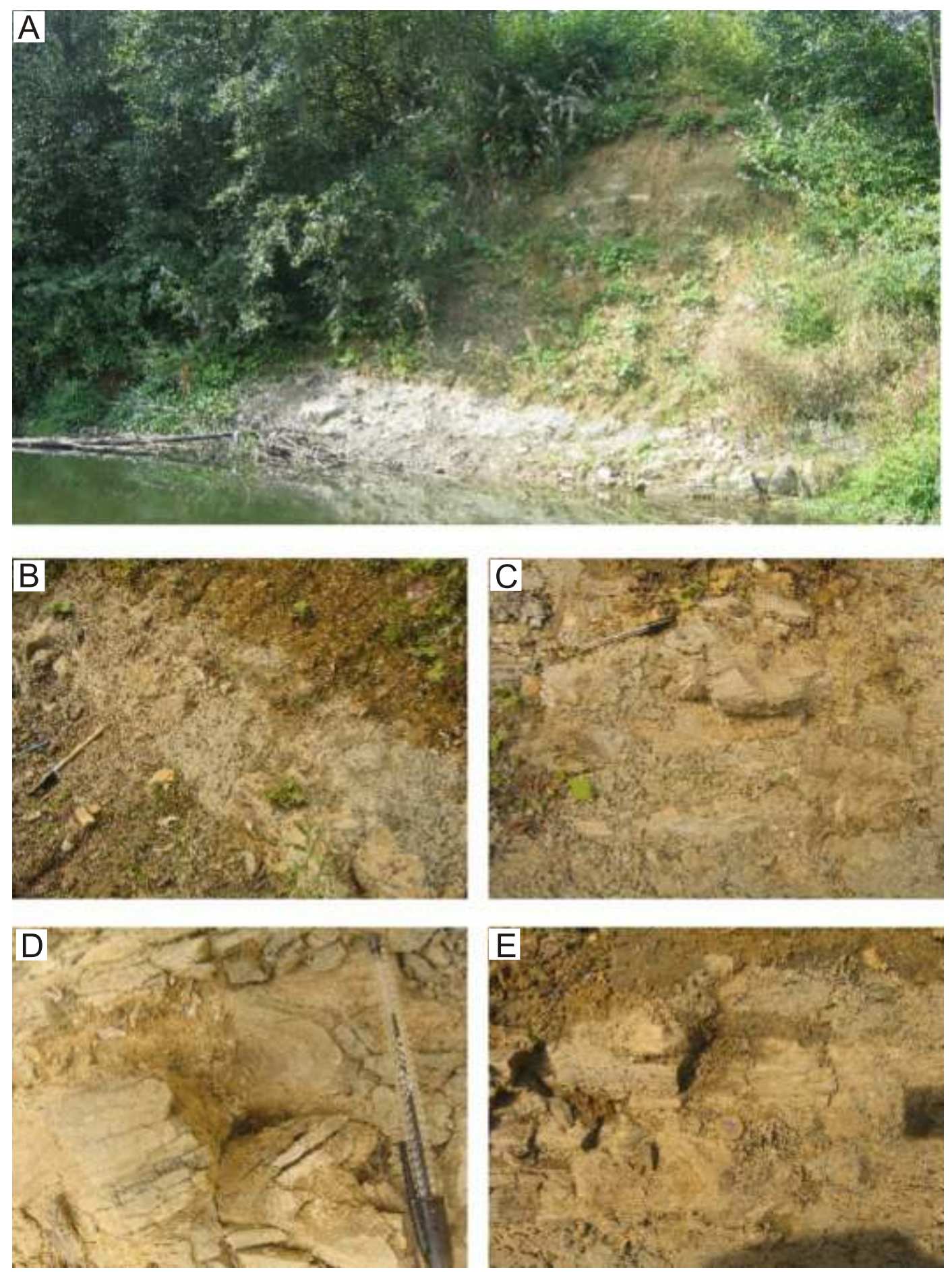

Fig. 3. Localition of the samples - the exposure of the Stare Bystre Formation on the boundary between the villages of Rogoźnik and Stare Bystre in 2006

A, B - general view of the exposure; C, D, E - yellowish marly shales and soft marls with thin intercalation of calcareous sandstone; the small fold forms the front part of a small submarine slump within the marly shales

have been described from two localities (Zaskale and Rogoźnik/Stare Bystre). The nannoplankton assemblages are characterized by the presence of Discoaster druggii, Sphenolithus ciperoensis, Sph. heteromorphus, Sph. abies, Helicosphaera ampliaperta, H. recta, Reticulofenestra pseudoumbilica and Discoaster kugleri. Based on the nannofossil content, Smagowicz (in Cieszkowski et al., 1991) determined the age of
Stare Bystre Formation as Middle Miocene. The foraminifer analysis was conducted by Olszewska (in Cieszkowski et al., 1991). The assemblage determined contained such species as: Globorotalia miozea Finlay, Gl. ex gr. foshi Cushman, Gl. praemenardi Cushman, Globigerina bolli Citta et Premoli Silva, G. druryi Akkers, G. diplostomata Reuss, Gl. explicationis Jenkins and Gl. ex gr. languaensis Bolli. According to Olszewska 
(in Cieszkowski et al., 1991) such an association allows for the determination of a Middle Miocene age for the Stare Bystre Formation. Gedl (1995), on the basis of a dinoflagellate association, described the age of the deposits from Rogoźnik as Middle Eocene (Rhombodinium draco Zone).

The Kopaszyska Beds were initially called the Zaskale layers (see Cieszkowski, 1992). They consist of yellowish, slightly cohesive, fine to medium, rarely coarse-grained and conglomeratic sandstones, occasionally with the occurrence of shales and mudstone clasts. These deposits are poor in microfauna, and mostly represented by agglutinated foraminifers: Rhabdammina sp. Taking into account the stratigraphic position, i.e. above the Stare Bystre Formation, the age was estimated as Middle Miocene.

The youngest deposits described by Cieszkowski et al. (1991) belong to the Pasieka Beds, developed as soft marls and clays, and also of Middle Miocene age. Age estimation of the youngest divisions was based on stratigraphic position, not confirmed by biostratigraphic data. According to Cieszkowski (1992) the upper part of these deposits are probably the Szaflary clays described by Friedberg $(1906,1909)$.

\section{SECTION STUDIED}

The area studied is located between the villages of Stare Bystre and Rogoźnik. The section (Fig. 3A, B) was situated on the left bank of the Rogoźnik Wielki Creek (GPS coordinates: N49 26.506, E19 55.836). Currently the section is completely covered by fluvial deposits, probably as an effect of stream expansion. For that reason the description below is based on the available literature (Cieszkowski et al., 1991; Cieszkowski, 1992, 1995; Cieszkowski and Struska, 2009). The beds were observed in inverted position, the dip of the layers facing to the NNW at an angle of $75-80^{\circ}$ (330/75). The Stare Bystre Formation is typically a flysch deposit. The main part of the profile consists of thick layers of marly shales and soft marls with intercalations of coarse-grained sandstones (calcareous, grey-bluish with two types of lamination: cross- and parallel, with muscovite and plant fragments). The upper part of the beds consists of thin-bedded sandstones with shale intercalations and plant fragments (carbonized detritus) while the lower part comprises fine-grained non-calcareous grey sandstones (Cieszkowski, 1992). Within the marly sequence, slump units of mudstone with marl clasts and detritus were reported. The top of the lithostratigraphic subdivision in the profile passes into coarse-, medium- and fine-grained, thick-bedded sandstones typical of the Magura Formation with intercalations of marls and marly shales, of the Łącko type (Fig. 4).

\section{METHODS AND MATERIALS}

18 samples (collected by the third author) for calcareous nannofossil analyses, were prepared using standard smear slide techniques for light microscope (LM). The investigation was carried out using a Nikon-Eclipse E 600 POL, microscope at a magnification of $1000 x$ using parallel and crossed polars. Quantitative analyses were performed using counts of 300 specimens per slide. In order to analyse and calculate the percentage abundance of autochthonous and allochthonous as- semblages a $5 \%$ range error was accepted. The nominal values and percentages are shown in Appendix $1^{*}$.

The state of preservation of calcareous nannofossils was assessed using the criteria of Roth and Thierstein (1972), Roth (1973) and Bown (1998). These are: G (good preservation) small dissolution of skeletons with minimum overgrowth, where recognition of species did not cause any problems, $M$ (moderate preservation) - specimens were mechanically broken but still easy to recognize, $P$ (poor preservation) - specimens showed mechanical fragmentation and also overgrowths, VP (very poor preservation) - where taxa were mostly in fragments. Also an attempt to separate different stages of preservation and overgrowth was made. Following Roth and Thierstein (1972), Roth (1973) and Bown (1998), six groups were considered (3 of mechanical degradation and 3 of overgrowth):

Mechanical dissolution:

$\mathrm{E} 1$ - where delicate structures were destroyed, in coccolith species serrate outlines were recognized. Cross-structures in Chiasmolithus sp. and also in species such as Pontosphaera, Rhabdosphaera were still observed; E2 - where central structures were destroyed (such as the grill, or cross). More delicate species were still observed (for example Sphenolithus and Helicosphaera); E3 - only the most resistant species survived Coccolithus, Discoasters, Reticulofenestrid etc.

Overgrowth:

O1 - rays of Discoasters were thickened, some elements of placoliths are overgrown;

$\mathrm{O} 2$ - rays were more thickened, ray tips were not recognized;

O3 - individual species of Discoaster were not recognizable. Placoliths covered strongly by calcite, identification was difficult.

In the samples investigated, attempts to accurately determine the conservation status of the species caused many difficulties, due to several sources of reworked material. In all samples various states of preservation of each species were visible. Therefore, in Appendix 1, the states of preservation were given in ranges.

In most samples the state of preservation of the species varied from moderate to good taking into account the 1 st and 2nd level of overgrowths.

After Bown and Young (1998), species abundance levels were divided into 5 groups:

1. Very high $(\mathrm{VH})>20$ taxa per 1 field of view;

2. High $(\mathrm{H})$ 10-20 taxa per 1 field of view;

3. Moderate (M) 5-10 taxa per 1 field of view;

4. Low (L) 1-5 taxa per 1 field of view;

5 . Very low $(L)<1$ taxon per 1 field of view.

In most of samples, frequency of species occurrence reached level 1 (very high) to level 2 (high). The states of preservation in individual samples are shown in Appendix 1.

\section{RESULTS}

\section{DESCRIPTION OF THE NANNOPLANKTON ASSEMBLAGES}

All samples were analysed under the microscope. During the analysis 128 species of calcareous nannofossils were determined Appendix 2. The species identified were divided into three assemblages containing: autochthonous, reworked and long-ranging taxa (Fig. 5).

* Supplementary data associated with this article can be found, in the online version, at doi: 10.7306/gq.1277 

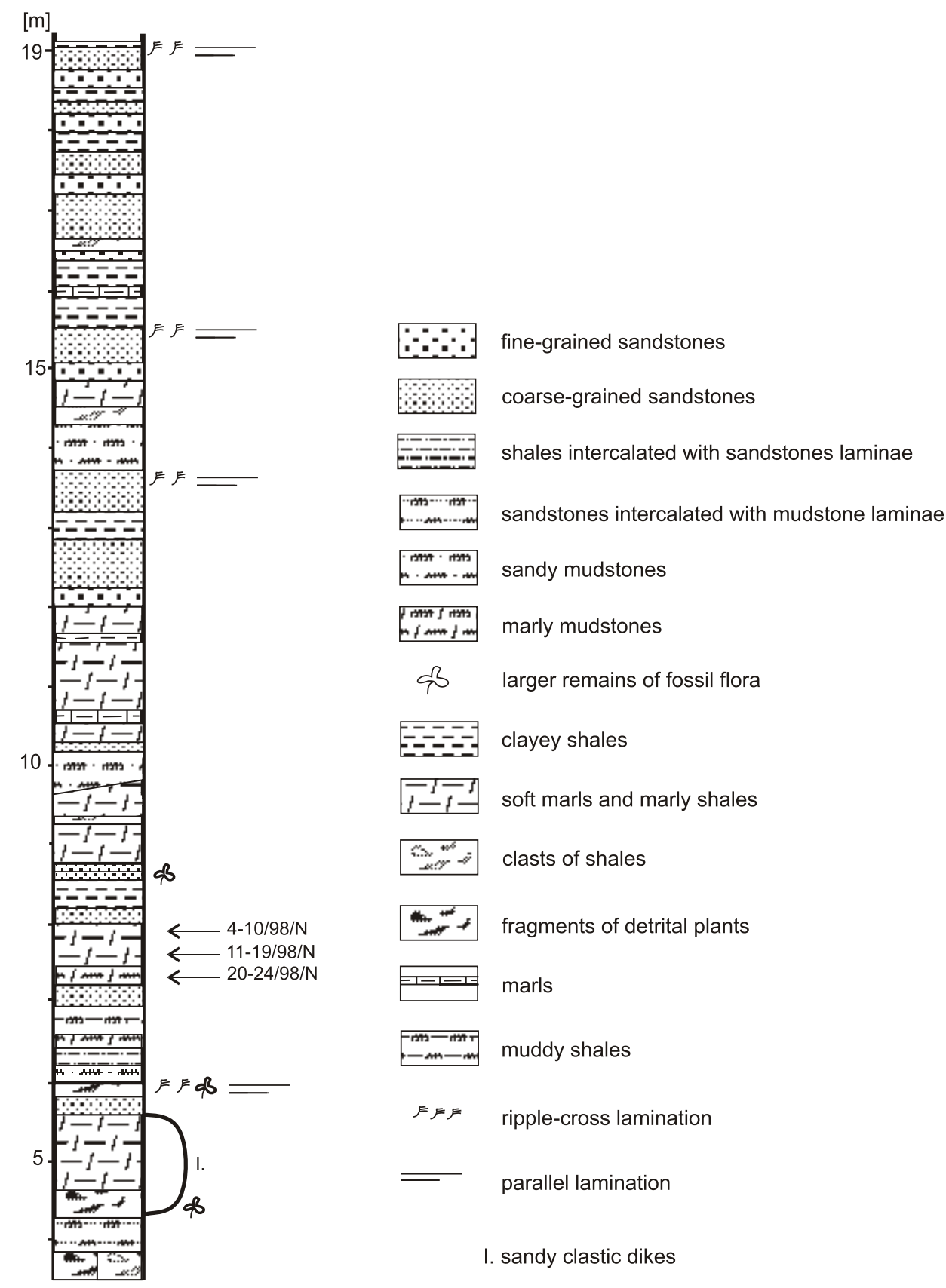

Fig. 4. Lithostratigraphical logs of the Stare Bystre Formation (after Cieszkowski, 1992)

\section{AUTOCHTHONOUS ASSEMBLAGES}

The autochthonous assemblage consists of 13 taxa. The highest share $(8.1-13 \%)$ of autochthonous species was observed in the samples $24 / 98 / \mathrm{N}, 20 / 98 / \mathrm{N}$ and $5 / 98 / \mathrm{N}$. Autochthonous species observed almost in all samples were: Coronocyclus nitescens (Fig. 6E, F), Pontosphaera multipora, Spenolithus disbelemnos (Fig. 6P-U) and Sph. dissimilis (Fig. $6 \mathrm{~W}, \mathrm{Y}$ ). Other species, found only in some samples were: Braarudosphaera bigelowii (Fig. 6A), Calcidiscus leptoporus (Fig. 6B), Discoaster deflandrei (Fig. 6H), Helicosphaera carteri (Fig. 6J-M), H. obliqua, Reticulofenestra daviesii, R. minuta and $R$. haqii. Percentages of the most abundant autochthonous taxa are shown in Figure 7.

The highest percentage of all taxa determined was of Coronocyclus nitescens. The highest rate of occurrence of this species was found in samples 6/98/N (2.2\%) and 5/98/N $(1.9 \%)$. Clacidiscus leptoporus is most abundant in samples $24 / 98 / \mathrm{N}$ and $8 / 98 / \mathrm{N}(2.2 \%)$. However, this species was not observed in 5 samples, making its overall percentage smaller than that of other two species from that group. The percentage of Pontosphaera multipora was significantly higher than that of Calcidiscus leptoporus (Appendix 1), the highest rate of occurrence of this species being found in samples 16/98/ $\mathrm{N}$ and 


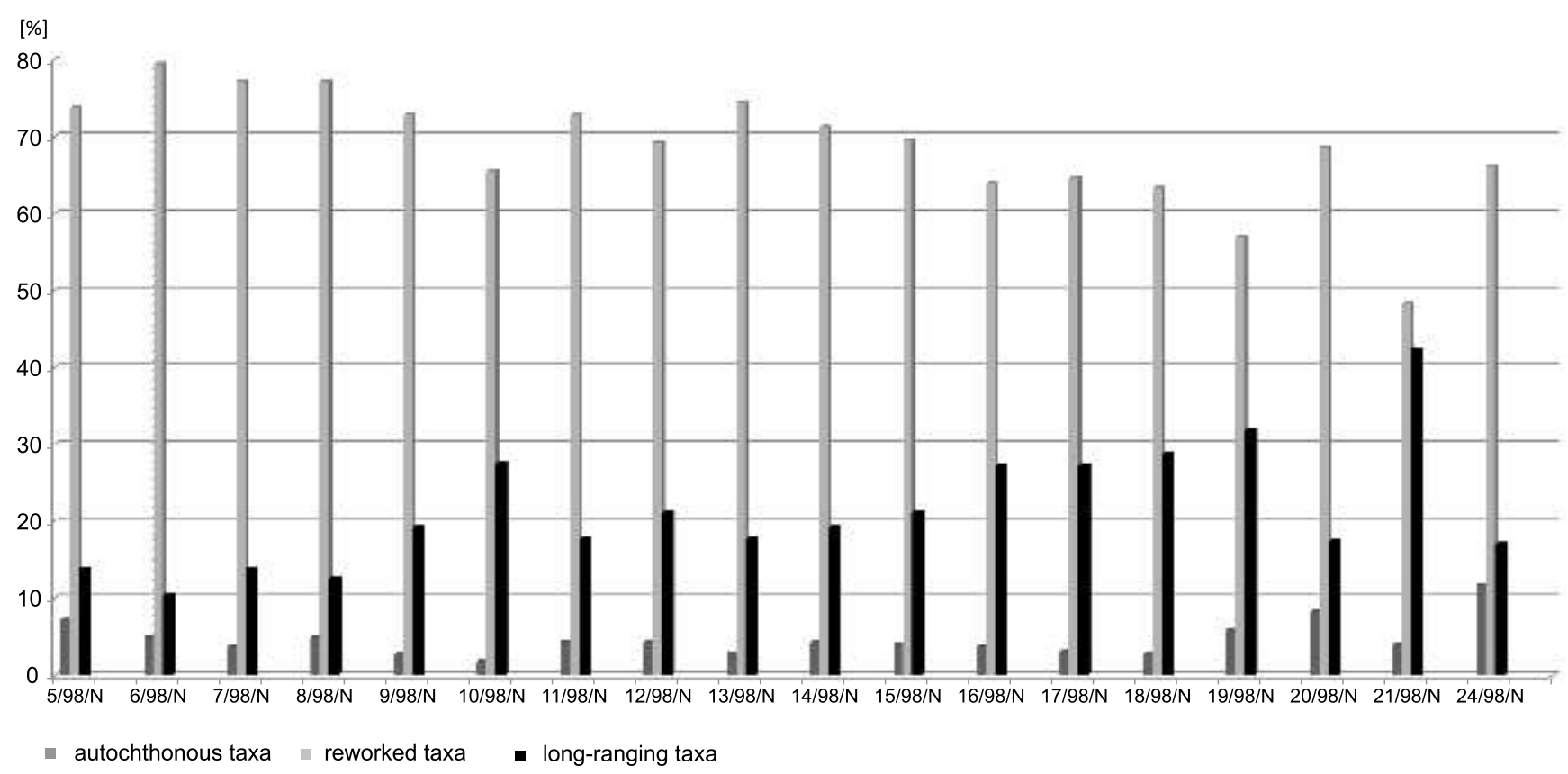

Fig. 5. The percentage of autochthonous, reworked and long-ranging taxa in the samples collected from the Stare Bystre section

19/98/N (2.5\%) (Fig. 7). Other species in the autochthonous group were observed in smaller quantities; in most cases they did not reach 6\%, with two exceptions: Reticulofenestra minuta (8.6\%) and Sphenolithus conicus (Fig. 6P, R), which almost reached $10 \%(9.8 \%$ in total percentage; Appendix 1$)$.

\section{REWORKED ASSEMBLAGES}

In all samples 112 reworked taxa were recognized. These were mainly Paleogene and Eocene species.

In almost all samples species of the genus Fasciculithus were identified. In reworked assemblages, some Cretaceous species were also observed, which because of their low amounts were not determined to species level. The samples also included representatives of the genus Ericsonia the size of which did not allow species-level identification. In Appendix 1 these specimens were described as "small Ericsonia". The greatest species diversity in the reworked assemblages was observed in the genera Chiasmolithus, Discoaster or Sphenolithus. The variability of the percentage of each species within the genus is shown on the Figure 8.

The highest content of the genus Chiasmolithus was observed in sample 19/98/N (almost 3.5\% - Fig. 8). The most common species is Chiasmolithus grandis, the percentage of all samples reaching $7.3 \%$ (Appendix 1 ), most frequently represented in the samples $8 / 98 / \mathrm{N}$ and $19 / 98 / \mathrm{N}$. Other frequently occurred species within the genus included Chiasmolithus solitus (3.8\%), most numerous in sample $8 / 98 / \mathrm{N}$ and Chiasmolithus expansus (3.5\%), most frequent in sample 19/98/N (Appendix 1).

The highest content of the genus Discoaster was observed in sample 16/98/N (almost 10.8\% - Fig. 8). The most common species in the genus Discoaster was Discoaster barbadiensis, the percentage of its appearances in all samples being $12.7 \%$ (Appendix 1); it was most often observed in sample 16/98/N. The highest content of the genus Sphenolithus was observed in sample 6/98/N (Fig. 8).
Within the genus Sphenolithus the most common species was Sph. radians, the sum of the percentage occurrences of that species in all samples amounting to $20.3 \%$ (Appendix 1). It was most widely represented in the samples 6/98/N, 8/98/N and $19 / 98 /$ N. Another frequently observed species was Sph. editus $(8.55 \%)$, its highest share of species being in sample $8 / 98 / \mathrm{N}$ (Appendix 1).

Among reworked assemblages in each sample, Blackites spinosus, Ericsonia formosa, Semihololithus kerabyi, Toweius callosus, T. magnicrassus, T. rotundus, Zygrhablithus bijugatus and numerous Transversopontis pulcher and Tribrachiatus orthostylus were also observed. The highest contribution of reworked taxa in samples from the profile in Stare Bystre amounted to $79.5 \%$ in sample 6/98/N (Fig. 9). The most numerous species represented in the allochthonous assemblages were Zygrhablithus bijugatus, Toweius rotundus, T. callosus and Blackites spinosus (Fig. 9). The percentage of Zygrhabilitus bijugatus in three samples (18/98/N, 13/98/N and $15 / 98 / \mathrm{N}$ ) is $>15 \%$ (Fig. 9). The percentage of Toweius rotundus in three samples $(11 / 98 / \mathrm{N}, 6 / 98 / \mathrm{N}$ and $7 / 98 / \mathrm{N})$ is $>15 \%$ and in the sample 20/98/N the species is absent (Fig. 9). The percentage of Blackites spinosus vary, the highest percentages being observed in samples $9 / 98 / \mathrm{N}$ and $16 / 98 / \mathrm{N}$, while this species was not observed in samples $15 / 98 / \mathrm{N}$ and 19/98/N (Fig. 9). The smallest percentage in described parts of the reworked assemblages comprised Toweius callosus, identified in all samples studied (Fig. 9).

\section{LONG-RANGING TAXA}

In all samples considered, besides a significant level of redeposited taxa, species with very long stratigraphic ranges, were also observed. For this reason, they were not included in autochthonous or reworked assemblages, and have been separated as a group of long-ranging taxa. These species are mostly cosmopolitan and also resistant to poor environmental 

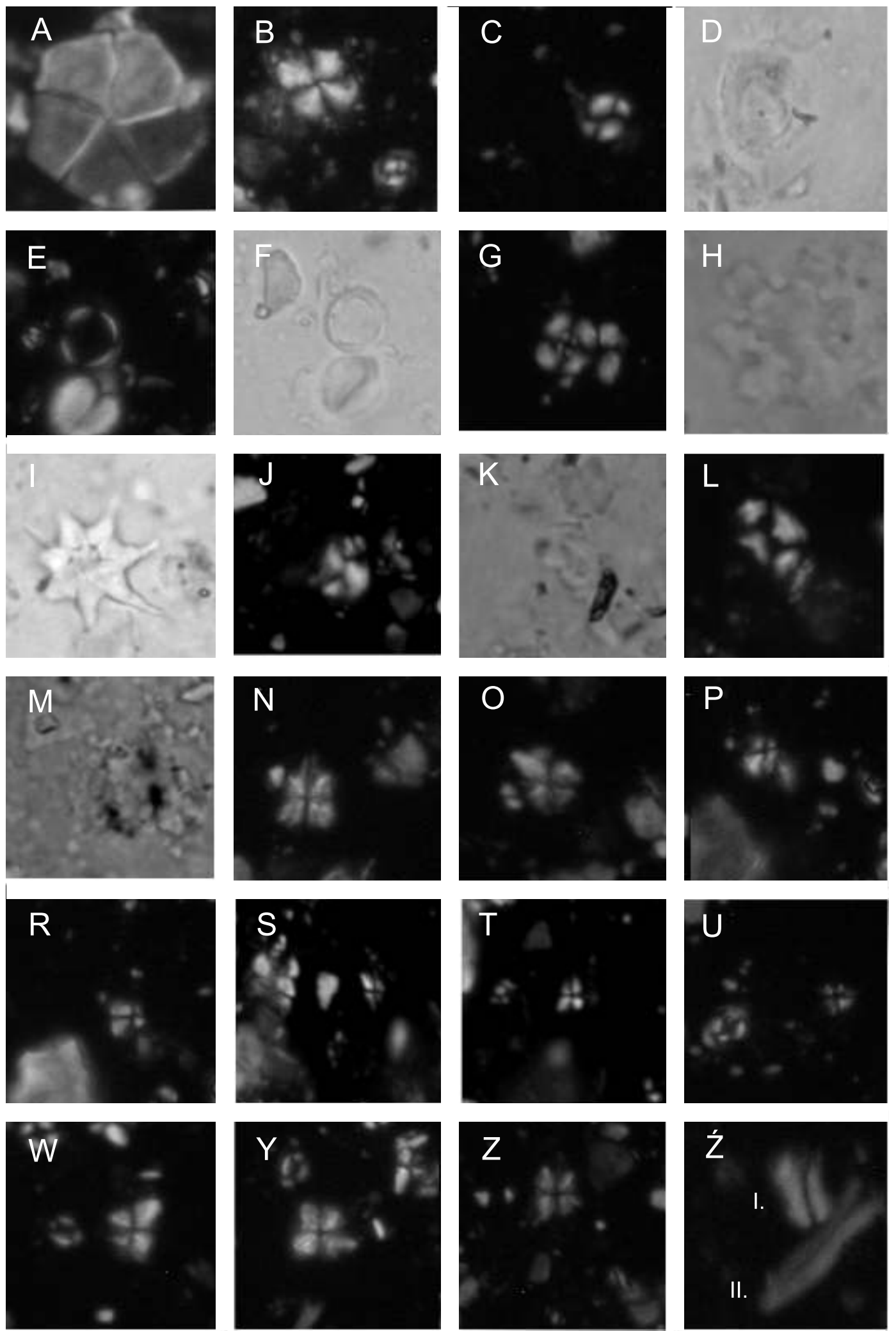

$10 \mu \mathrm{m}$ 
[\%]

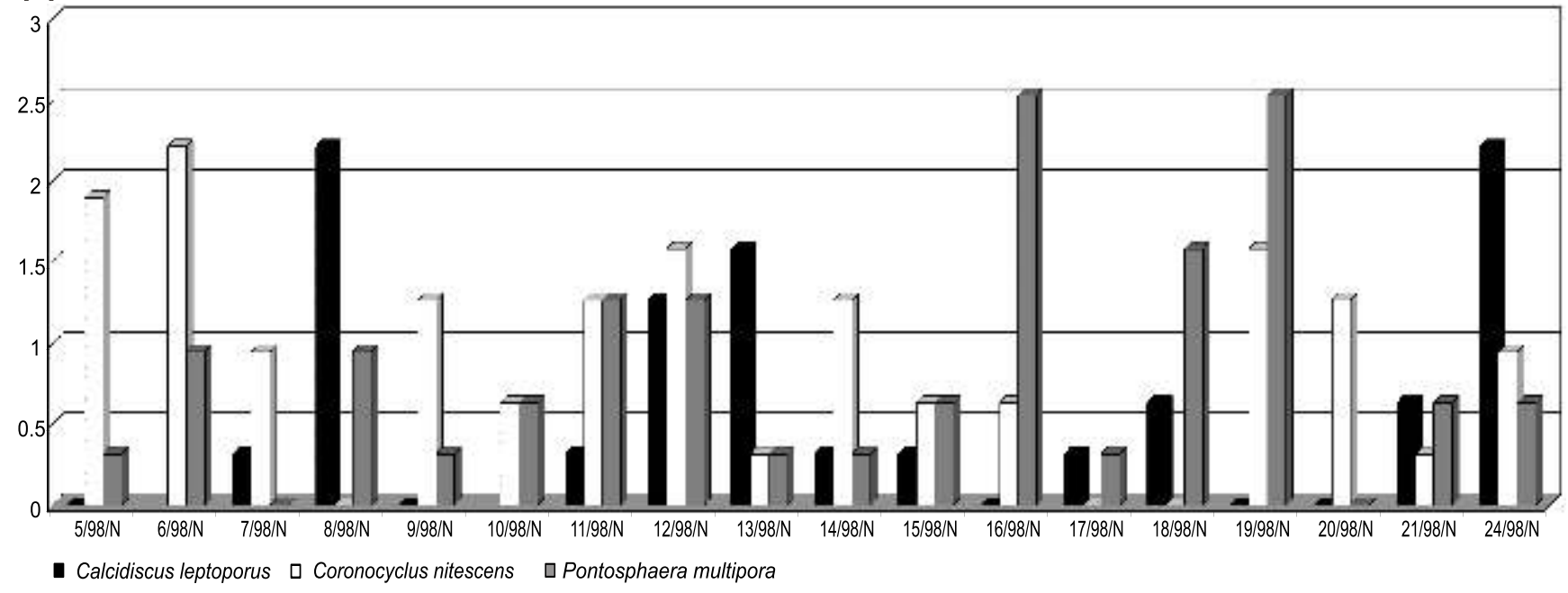

Fig. 7. The variability of the percentage of the most abundant autochthonous taxa in samples from the Stare Bystre section

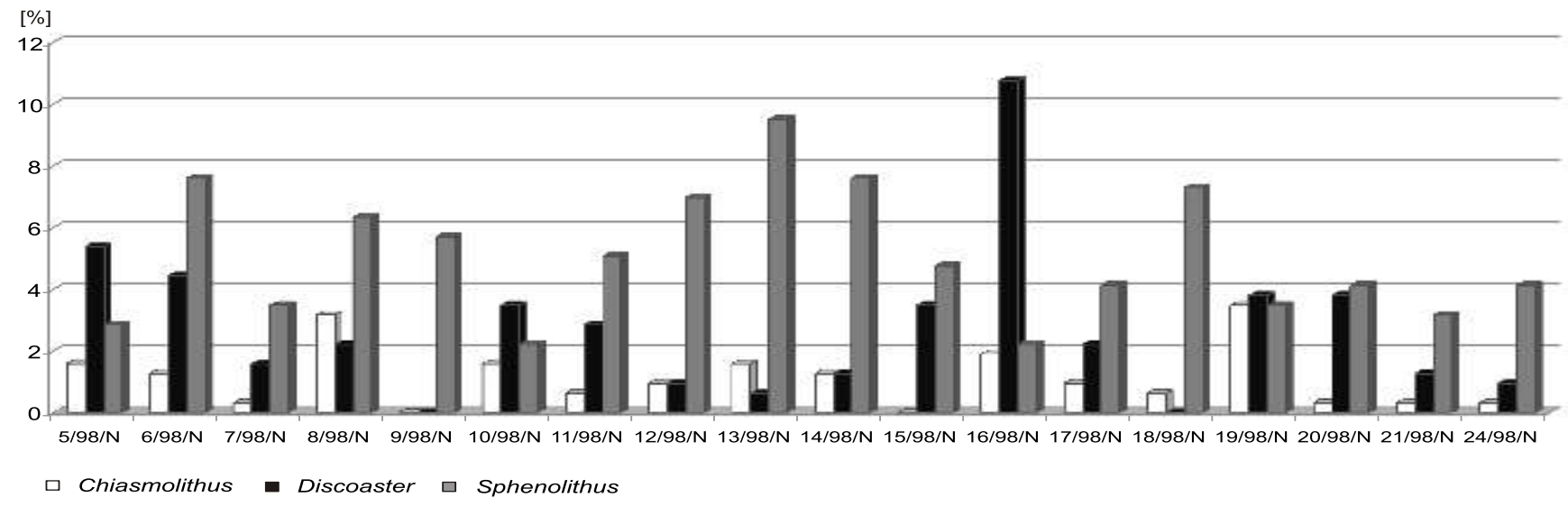

Fig. 8. The percentage of variability of individual species within the genus Sphenolithus, Discoaster and Chiasmolithus in samples from the Stare Bystre village exposure

Fig. 6. LM microphotographs of calcareous nannofossils from samples from the Stare Bystre Formation

A - Braarudosphaera bigelowii (Gran and Braarud, 1935) Deflandre (1947) sample11/98/N (xN); B - Calcidiscus leptoporus (Murray and Blackman, 1898) Loeblich and Tappan (1978) sample 24/98/N (xN); C - Coccolithus pelagicus (Wallich, 1877) Schiller (1930) sample 14/98/N (xN); D - Coccolithus pelagicus (Wallich, 1877) Schiller (1930) sample 14/98/N (1N); E - Coronocyclus nitescens (Kamptner, 1963) Bramlette and Wilcoxon (1967) sample 20/98/N (xN); F - Coronocyclus nitescens (Kamptner, 1963) Bramlette and Wilcoxon (1967) sample 20/98/N (1N); G - Cyclicargolithus luminis (Sullivan, 1965) Bukry (1971) (xN); H - Discoaster deflandrei (Bramlette and Riedel, 1954) sample 5/98/N (1N); I - Discoaster lodoensis (Bramlette and Riedel, 1954) sample 8/98/N (1N); J - Helicosphaera carteri (Wallich, 1877) Kamptner (1954) sample 4/98/N (xN); K - Helicosphaera carteri (Wallich, 1877) Kamptner (1954) sample 4/98/N (1N); L - Helicosphaera carteri (Wallich, 1877) Kamptner (1954) sample 24/98/N (xN); M - Helicosphaera carteri (Wallich, 1877) Kamptner (1954) sample 24/98/N (1N); N, O - Sphenolithus conicus (Bukry, 1971) sample 5/98/N (xN); P-U - Sphenolithus disbelemnos (Fornaciari and Rio, 1996) sample 21/98/N (xN); W, Y - Sphenolithus dissimilis (Bukry and Percival, 1971) sample 6/98/N (xN); Z - Sphenolithus moriformis (Brönnimann and Stradner, 1960) Bramlette and Wilcoxon (1967) sample 12/98/N (xN); Ż - Zygrhablitus bijugatus (Deflandre in: Deflandre and Fert, 1954) Deflandre (1959) and Semihololithus kerabyi (Perch-Nielsen, 1971) (xN); I. - Zygrhablitus bijugatus, II. - Semihololithus kerabyi; $1 \mathrm{~N}$ - plane parallel polars, $\mathrm{xN}$ - crossed polars 


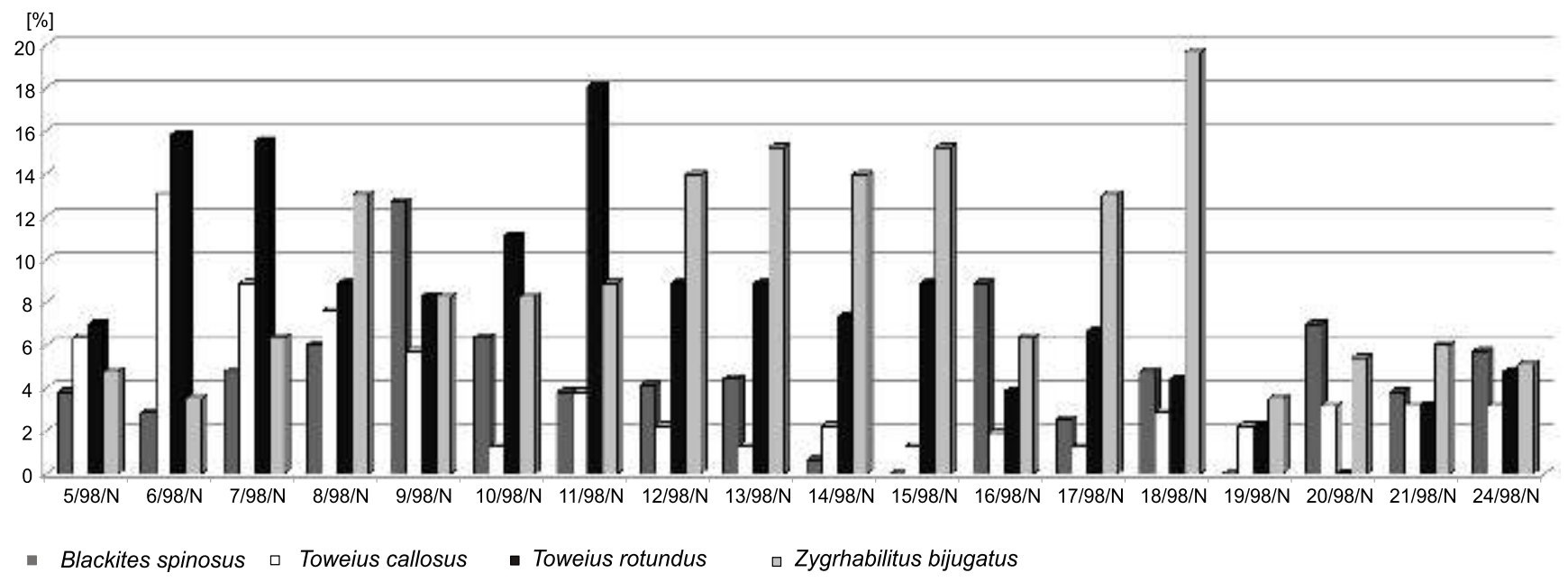

Fig. 9. The percentage of the most abundant allochthonous species in the assemblages from the Stare Bystre section

conditions. Among the group of heterococcoliths, two species in the genus Coccolithus were distinguished: C. pelagicus (Fig. $6 \mathrm{C}, \mathrm{D}$ ) and $C$. eopelagicus (range of occurrence from Danian to recent), and two species from the genus Cyclicargolithus: $C y$. floridanus (Eocene to Miocene) and Cy. abisectus (Oligocene to Early Miocene). In that group one species of Sphenolithus Sph. moriformis (Fig. 6Z; Eocene to Late Miocene) was noted and also one species from the nannolith family: Braarudosphaera bigelowii (Fig. 6A) - which occurs in the oceans to the present day, associated with a neritic environment (Gran and Braarud, 1935).

\section{INTERPRETATION}

\section{BIOSTRATIGRAPHY}

The age of the Stare Bystre Formation was established as Early Miocene - NN2, using standard nannoplankton zonation (Martini and Worsley, 1970). The age was determined on the basis of the co-occurrence of Cyclicargolithus floridanus, Helicosphaera carteri, Sphenolithus conicus, Sph. dissimilis and Sph. disbelemnos. According to Fornaciari and Rio (1996) and Young (1998) Sph. disbelemnos is typical of the NN2 Zone (Fig. 10). An astronomical age for Sph. disbelemnos was proposed by Shackleton et al. (2000; see also Raffi et al., 2005). The species appears at 22.67 Ma and it is shown to be an important datum level for the Paratethys region (Rögl and Nagymarosy, 2004; Oszczypko-Clowes in: Oszczypko et al., 2005a).

At the same time Dictyococcites bisectus, Cyclicargolithus abisectus and Zygrhablithus bijugatus are absent from this association. According to Perch-Nielsen (1985), Berggren et al. (1995), Fornaciari et al. (1996) and Young (1998) the LO of Dictyococcites bisectus defines the base of NN1. Thus, one can assume that the age of the Stare Bystre Formation is not older than NN2 (Aquitanian/Burdigalian).

\section{AGE OF THE REWORKED ASSEMBLAGES}

Redeposited species can help to decipher both the history of terrestrial erosion around the basin area, as well as the direction and intensity of the transport of eroded material. In the Magura succession, within the area investigated, flysch deposition was

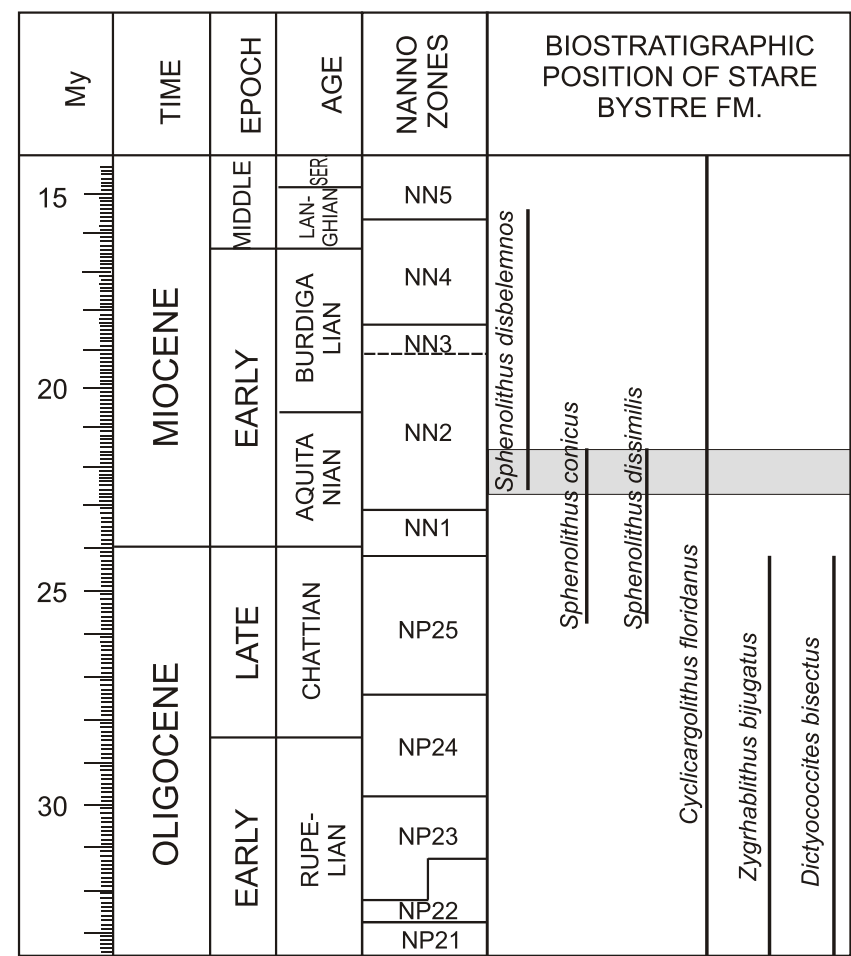

Fig. 10. Biostratigraphic position of the Stare Bystre Formation (grey field)

mainly observed, involving turbidity currents from a continental slope. Biostratigraphical studies have shown the very high utility of calcareous nannoplankton in turbidites. This is the result of the small size of nannofossils with at the same time large numbers of various taxa preserved in a small portion of rock (Siesser, 1993). Calcareous nannoplankton are ideally preserved in mud-clay material, which forms a natural shield to the small nannofossil skeletons, protecting them from degradation during transport (Mikes et al., 2008; Oszczypko-Clowes, 2012). In the samples examined, the proportion of reworked taxa reaches $>50 \%$ of all observed species. The age of the reworked assemblages varies across a wide time range. In the material studied, Cretaceous, Paleocene, Eocene and Oligocene taxa were observed, though with noticeable, significant predominance of Paleogene taxa over Cretaceous ones (Fig. 11). 
The contribution of Cretaceous species in reworked assemblages does not exceed $5.07 \%$ (sample $24 / 98 / \mathrm{N}$ ), whereas the Paleogene species can reach $>80 \%$ of all species in the samples investigated (Fig. 6).

The assemblages are mixed with species from different time intervals:

- The Lower Eocene assemblage is represented by Discoaster multiradiatus (range: NP9-11), Discoaster lodoensis (NP12-14; Fig. 6I) and Tribrachiatus orthostylus or Toweius crassus.

- The presence of the Middle Eocene (NP15 zone) could be dated by the Chiasmolithus gigas zonal marker or by Nanotetrina quadrata.

- Long-ranging species, spanning from the Mid Eocene to the Early Oligocene, include: Discoaster tanii nodifer (NP16-22), Helicosphaera bramlettei (NP14-23), Lanternithus minutus (NP16-22), Reticulofenestra umbilica (NP16-22), Discoaster barbadiensis (NP10-20), Dictyococcites bisectus (NP17-24), Discoaster saipanensis (NP14-23) and Ismolithus recurvus (NP19-22).

- In addition, typical Oligocene taxa include: Sphenolithus ciperoensis (FO), Pontosphaera latelliptica, Transversopontis fibula and, very rarely, Sph. capricornutus and Sph. calyculus.

\section{DISCUSSION}

The age of the Stare Bystre Formation was assigned to the Early Miocene - Aquitanian/Burdigalian (NN2 Zone). The age determination was made on the presence of Sphenolithus disbelemnos in almost all samples (Fig. 6P-U) which according to Young (1998) is an index species for the lower part of the NN2 nannoplankton zone. Such age determination is in contrast to the previous works describing the age of Stare Bystre
Formation as Middle Miocene (Badenian/Sarmatian) (Cieszkowski et al., 1991; Cieszkowski, 1992, 1995). The age of the deposits in previous works was based on the presence of Discoaster drugii, Sphenolithus ciperoensis, Sph. heteromorphus, Sph. abies, Helicosphaera ampliaperta, H. recta, Reticulofenestra pseudoumbilica and Discoaster kugleri (Smagowicz in Cieszkowski et al., 1991). According to the previous works considering the standard zonation of Martini (1971) and Martini and Worsley (1970), the first occurrence of Reticulofenestra pseudoumbilica takes place in NN5, however, this taxon was reported by Marunteanu (1991) from the lower limit of NN2, while Holcová (2013) also questioned the Middle Miocene age of Reticulofenestra pseudoumbilica. Holcová (2013) divided the reticulofenestrid group on the basis of their size and also noticed differences between the first appearances of these species in the global ocean and in the Central Paratethys, in which the larger species appear a little earlier. According to Holcová (2013), the smallest species (i.e. $R$. haqii $<4 \mu \mathrm{m}$ ) has a FO (first occurrence) in zone NP25 in the Paratethys, whereas in the global ocean it was in zones NN1/NN2. Similarly the species of $R$. pseudoumbilicus $>5 \mu \mathrm{m}$ first reportedly appeared at the end of the Oligocene. Holcová (2013) also suggested that different sizes in the $R$. haqii-pseudoumbilicus group depended on the seasonality in the ocean (smaller species in winter and larger in the summer). Larger taxa of Reticulofenestrid $>7 \mu \mathrm{m}$ (Holcova, 2012) appear in the NN4 Zone and $>8 \mu \mathrm{m}$ in the NN5 Zone. Cieszkowski et al. (1991) did not mention the size of Reticulofenestra pseudoumbilicus and therefore a reference to this species will not be considered.

In our opinion, the most important species mentioned by Smagowicz (in Cieszkowski et al., 1991), which determined the age of the Stare Bystre Formation are: Sphenolithus abies, the first appearance of which is in the NN6 Zone (Sarmatian, Tortonian) (Perch-Nielsen, 1985; Bown, 1998), and Discoaster kugleri, which is an index taxa for the NN7 Zone (Sarmatian) in the standard zonation (Martini, 1971).

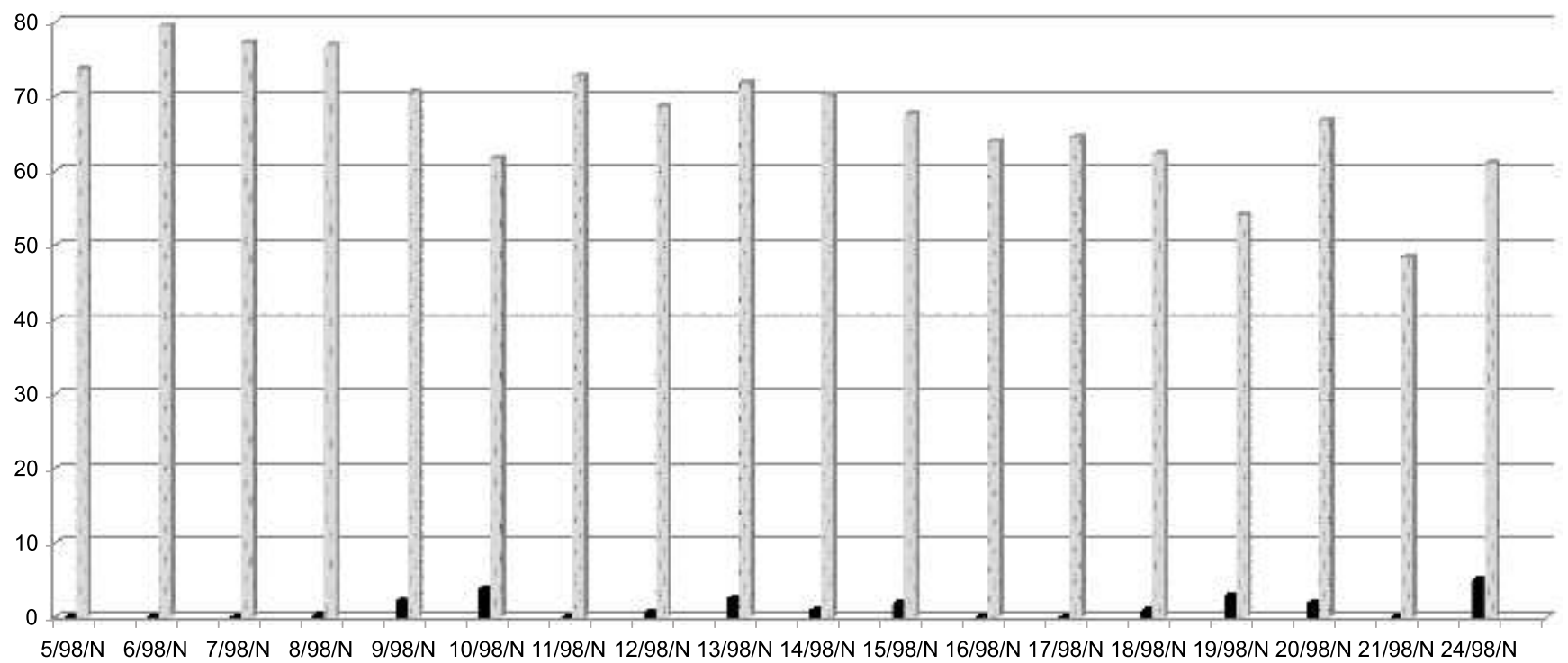

Cretaceous species

Paleogene species

Fig. 11. Comparison of the percentage of Cretaceous and Paleogene species in individual samples from the Stare Bystre profile 
Species such as: Discoaster drugii, Sphenolithus ciperensis, Sph. heteromorphus, Sph. abies, Helicosphaera ampliaperta, H. recta, Reticulofenestra pseudoumbilica and Discoaster kugleri are not present. In such cases the Middle Miocene age of Stare Bystre Formation cannot be supported.

The autochthonous assemblage shows mostly temperate and warm-water taxa, typical of the gradual Early Miocene increase in surface water temperature. These include Sphenolithus species such as Sph. conicus (Fig. 6N, O), Sph. disbelemnos (Fig. 6P-U) and Sph. dissimilis (Fig. 6W, Y). Also, the following species were observed in all samples: $D$. deflandrei (Fig. $6 \mathrm{H}), H$. carteri and $H$. obliqua. In the long-ranging group there was also noticeable Cyclicargolithus floridanus which is an indicator of temperate water (Wei and Wise, 1990).

From the lithological point of view the Stare Bystre Formation is characterized by the occurrence of Magura-type sandstones and thin-bedded flysch layers with the Łącko type of marlstones. Considering the age, qualitative and quantitative composition of nannoplankton assemblages and also lithofacies compositions, a strong correlation between the Stare Bystre Formation and the Kremna and Zawada formations is noticeable (cf. Oszczypko et al., 1999, 2005a; Oszczypko and Oszczypko-Clowes, 2002; Oszczypko-Clowes, 2012).

Within reworked assemblages a significant predominance of Paleogene species over Cretaceous ones was observed, from which one can infer that they were transported with the mass of sediment in gravity flows. All Paleogene species within the reworked assemblages were better preserved than indigenous or Cretaceous ones, and have a much larger size suggesting a good resistance to mechanical damage during transport. With the growth of the accretionary prism, eroded older material (from Cretaceous deposits) also appeared. In the samples within the reworked assemblages younger Oligocene taxa were also observed, suggesting the presence of another source of material. This could have been the products of erosion of younger deposits from the bottom of the basin, probably related to the presence of mud volcanoes, which in combination of dehydration of the material led to extraction and erosion from the bottom of the basin. This type of process is characteristic of the dynamics of an accretionary prism (Mikes et al., 2008;
Oszczypko-Clowes, 2012). A similar degree of redeposition were described in the Miocene turbidity deposits from the PKB and also other Magura Nappe zones: Krynica, Tylicz and Bystrica, e.g. within the Kremna Formation (Oszczypko-Clowes in: Oszczypko et al., 2005a) or Zawada Formation from the Lubovnianska Vierchovina sections (Oszczypko and Oszczypko-Clowes, 2002). During the Late Oligocene (NN25/NN1) the frontal part of the Magura Nappe thrust northwards onto the terminal Krosno flysch basin. The northwards thrusting of the Magura Nappe was accompanied by the formation of the piggy-back basin on the Magura Nappe, filled with the synorogenic turbidites belonging to the Zawada (Oszczypko et al., 1999), Kremná (Oszczypko at al., 2005a) and Stare Bystre formations (NN2). During the Early/Middle Miocene, the Magura Nappe was finally folded and flatly thrust northwards over the Fore-Magura Group of Nappes and, together with these, upon the Silesian Nappe.

\section{CONCLUSIONS}

1. On the basis of calcareous nannoplankton, the age of the Stare Bystre Formation was assigned to the Burdigalian age (NN2 Zone).

2. Nannofossil analyses did not confirm a Badenian-Sarmatian age for the Stare Bystre Formation.

3. The nannofossil assemblages show high contents of reworked species which are mostly of Eocene and Oligocene age.

4. On the basis of lithological and biostratigraphical similarities, the Stare Bystre Formation can be correlated with the Kremna and Zawada formations.

Acknowledgements. The authors express their profound gratitude to all the reviewers of this work (K. Holcová, Anonymous and D. Ghita) for their insightful comments, important suggestions and help in the process of writing, and to the editors, T.M. Peryt and E. Dąbrowska-Jędrusik, for their editorial assistance.

\section{REFERENCES}

Berggren, W.A., Kent, D.V., Swiser III., C.C., Aubry, M.P., 1995. A revised Cenozoic geochronology and chronostratigraphy. SEPM Special Publications, 54: 129-212.

Birkenmajer, K., 1951. La question du Miocène marin de Podhale (Karpates Centrales) (in Polish with French summary). Rocznik Polskiego Towarzystwa Geologicznego, 21: 235-278.

Birkenmajer, K., 1954. Geological investigations of the Podhale Neogene, Central Carpathians (in Polish with English summary). Biuletyn Instytutu Geologicznego, 86: 59-79.

Birkenmajer, K., 1958. Przewodnik geologiczny po pienińskim pasie skałkowym (in Polish). Wyd. Geol., Warszawa.

Birkenmajer, K., Dudziak, J., 1988. Nannoplankton dating of terminal flysch deposits (Oligocene) in the Magura Basin, Outer Carpathians. Bulletin of the Polish Academy of Sciences, Earth Sciences, 36: 1-13.

Bown, P.R., 1998. Calcareous Nannofossil Biostratigraphy. Kluwer Academic Publisher, U.S.A.
Bown, P.R., Young, J.R., 1998. Introduction. In: Calcareous Nannofossil Biostratigraphy (ed. P.R. Bown): 1-15. Chapman and Hall, Kluwer Academic.

Brönnimann, P., Stradner, H., 1960. Die Foraminiferen und Discoasteridenzonen von Kuba und ihre interkontinentale Korrelation. Erdoel-Zeitschrift für Bohr- und Foerdertechnik, 76: 364-369.

Bramlette, M.N., Riedel, W.R., 1954. Stratigraphic value of discoasters and some other microfossils related to Recent coccolithophores. Journal of Paleontology, 28: 385-403.

Bramlette, M.N., Wilcoxon, J., 1967. Middle Tertiary calcareous nannoplankton of the Cipero Section, Trinidad, W. I. Tulane Studies in Geology and Paleontology, 24: 44-60.

Bukry, D., 1971. Cenozoic calcareous nannofossils from the Pacific Ocean. San Diego Society of Natural History Transactions, 16: 303-327.

Bukry, D., 1978. Biostratigraphy of Cenozoic marine sediment by calcareous nannofossils. Micropaleontology, 9: 93-131. 
Bukry, D., Percival, S.F., 1971. New Tertiary calcareous nannofossils. Tulane Studies in Geology and Paleontology, 8: 123-146.

Cieszkowski, M., 1992. Marine Miocene deposits near Nowy Targ, Magura Nappe, Flysch Carpathians (South Poland). Geologica Carpathica, 43: 339-346.

Cieszkowski, M., 1995. Utwory morskiego miocenu w rejonie Nowego Targu i ich znaczenie dla określenia czasu powstania śródgórskiego zapadliska Kotliny Orawsko-Nowotarskiej (in Polish). Zeszyty Naukowe AGH, Kwartalnik Geologia, 21: 153-168.

Cieszkowski, M., Olszewska, B., 1986. Malcov beds in the Magura Nappe near Nowy Targ, Outer Carpathians, Poland. Annales Societatis Geologorum Poloniae, 56: 53-71.

Cieszkowski, M., Struska, M., 2009. Stop 6. Stare Bystre-Rogoźnik - morski miocen w płaszczowinie magurskiej - podło e neogenu Kotliny Orawsko-Nowotarskkiej. Część 2. Elementy geologii kotliny Orawsko-Nowotarskiej. In: Sesja terenowa A7. Tektonika fliszu podhalańskiego i Kotlina Orawsko-Nowotarska. D. Klimkiewicz, M. Ludwiniak (L. Mastella, M. Cieszkowski, W. Zuchiewicz, M. Struska and A.K. Tokarski); In: LXXIX Zjazd Polskiego Towarzystwa Geologicznego, Budowa geologiczna Tatr i Podhala ze szczególnym uwzględnieniem zjawisk geotermalnych na Podhalu, Bukowina Tatrzańska, 26-29.09.2009 r (eds. A. Uchman and J. Chowaniec): 154-158. Materiały konferencyjne. PIG, Warszawa.

Cieszkowski, M., Olszewska, B., Smagowicz, M., 1991. Utwory morskiego miocenu w okolicy Nowego Targu (in Polish). Sprawozdania z posiedzeń Komisji Naukowych PAN, 35: 245-249.

Deflandre, G., 1947. Braarudosphaera nov. gen., type d'une famille nouvelle de Coccolithophoridés actuels à éléments composites. Compte Rendu Hebdomadaire des Séances de l'Académie des Sciences, Paris, 225: 439-441.

Foetterle, F., 1851. Braunkohlenablagerung in dein Arvaer Coinitat. Jahrbuch der Kaiserlich-Königlichen Geologischen Reichsanstalt, 4: 160-161.

Fornaciari, E., Rio, D., 1996. Latest Oligocene to early Middle Miocene quantitative calcareous nannofossil biostratigrapy in the Medirerranean region. Micropaleontology, 42: 38-64.

Friedberg, W., 1906. Das Miozän der Niederung von Nowy Targ in Galizien. Sitzungsberichte der Akademie der Wissenschaften in Wien, 115: 779-792.

Friedberg, W., 1912. Einige Beobachtungen in den Galizischen Miocän-Gebieten (In Polish with Deutsch summary). Kosmos, Lwów, 37: 14

Friedberg, W., 1909. Erganzende Bemerkungen uber das Miozan von Nowy Targ in Galizien. Mitteilungen der Geologischen Gesellschaft, Wien, 2: 351-352.

Friedberg, W., 1920. Ètudes sur le miocène de la Pologne (in Polish with French summary). Kosmos, 45: 1-6.

Gedl, P., 1995. Middle Eocene dinoflagellate cysts from the Rogoźnik section, Flysch Carpathians, Poland. Acta Palaeobotanica, 35: 195-231.

Gran, H.H., Braarud, T., 1935. A quantitative study of the phytoplankton in the Bay of Fundy and the Gulf of Mine (including observations on hydrography, chemistry and turbidity). Journal of Biology, Board Canada, 1: 279-467.

Halicki, B., 1930. La glaciation quaternaire du versant nord de la Tatra (in Polish with French summary). Sprawozdania Państwowego Instytutu Geologicznego, 5: 377-534.

Haq, B.U., 1971. Paleogene calcareous nannoflora, parts I-IV. Stockholm Contributions in Geology, 11: 1-158.

Haq, B.U., Hardenbol, J., Vail, P.R., 1987. Chronology of fluctuating sea levels since the Triassic (250 million years ago to present). Science, 235: 1156-1167.

Holcová, K., 2013. Morphological variability of the Paratethyan Oligocene-Miocene small reticulofenestrid coccolithes and its paleoecological and paleogeographical implications. Acta Palaeontologica Polonica, 58: 651-668.

Kamptner, E., 1954. Untersuchungen über den Feinbau der Coccolithen. Archiv für Protistenkunde, 100: 1-90.
Kamptner, E., 1963. Coccolithineen-Skelettreste aus Tiefseeablagerungen des Pazifischen Ozeans. Annalen des Wiener Museums der Naturgeschichte, 66: 139-204.

Koszarski, L., Sikora, W., Wdowiarz, S., 1974. The Flysch Carpathians. Polish Carpathians. In: Tectonics of the Carpathian-Balkan Regions (ed. M. Mahel): 180-197. Geologický Ústav Dionyza Štura, Bratislava.

Loeblich, A.R. Jr., Tappan, H., 1978. The coccolithophoroid genus Calcidiscus Kamptner and its synonyms. Paleontology, 52: 1390-1392.

Łoziński, M., Wysocka, A., Ludwiniak, M., 2015. Neogene terrestrial sedimentary environments of the Orava-NowyTarg Basin: a case study of the Oravica River section near Čimhová, Slovakia. Geological Quarterly, 59 (1): 21-34.

Martini, E., 1971. Standard Tertiary and Quaternary calcareous nannoplankton zonation. Nature, 225: 280-290.

Martini, E., Worsley, T., 1970. Standard Neogene calcareous nannoplankton zonation. II. Proc. I I Planktonic Conf. Roma 1970, Edizioni Tecnoscienza, 729-785, Rome.

Marunteanu, M., 1991. Distribution of the Miocene calcareous nannofossils in the Intra- and Extra-Carpathian areas of Romania. In: Proceedings 4th INA Conference in Prague (eds. B. Hamršmíd and J. Young): 247-261.

Matašovsky, M., Andreyeva-Grigorovich, A.S., 2002. The Lower Miocene deposits of the Krynica Subunit of the Magura Nappe near Humenne (eastern Slovakia). In: Paleogeographical, Paleoecological and Paleoclimatic Development of Central Europe (eds. J. Michalik, N. Hudačková, B. Chalupová and D. Starek): 63-64. Conference in Bratislava. Abstract Book.

Mikes, T., Báldi-Beke, M., Kazmer, M., Dunkl, I., von Eynatten, H., 2008. Calcareous nannofossil age constraints on Miocene flysch sedimentation in the Outer Dinarides (Slovenia, Croatia Bosnia-Herzegovina and Montenegro). Geological Society Special Publications, 298: 335-363.

Oszast, J., 1970. On the age of the Domański Wierch cone determined by palynological methods (in Polish with English summary). Geological Quarterly, 14 (1): 1-42.

Oszczypko, N., 1973. The geology of the Nowy Sącz Basin (the Middle Carpathians) (in Polish with English summary). Biuletyn Instytutu Geologicznego, 271: 101-197.

Oszczypko, N., 1999. From remnant oceanic basin to collision-related foreland basin - a tentative history of the Outer Western Carpathians. Geologica Carpathica, 50 (spec. issue): 161-163.

Oszczypko, N., 2006. Pozycja polskich Karpat zewnętrznych w systemie alpejsko-bałkańskim oraz główne etapy rozwoju orogenu (in Polish). In: Rozwój paleotektoniczny basenów Karpat zewnętrznych i pienińskiego pasa skałkowego (eds. N. Oszczypko, A. Uchman and E. Malata). Instytut Nauk Geologicznych Uniwersytetu Jagiellońskiego, Kraków.

Oszczypko, N., Oszczypko-Clowes, M., 2002. Newly discovered Early Miocene deposits in the Nowy Sącz area (Magura Nappe, Polish Outer Carpathians). Geological Quarterly, 46 (2): 117-133.

Oszczypko, N., Oszczypko-Clowes, M., 2009. Stages in the Magura Basin evolution - a case study of the Polish Sector (Western Carpathians). Geodinamica Acta, 22: 83-100.

Oszczypko, N., Oszczypko-Clowes, M., 2010a. Budowa geologiczna okolic Krynicy-Zdroju i Muszyny (SE części Beskidu Sądeckiego, Zewnętrzne Karpaty Zachodnie). Mapa Geologiczna SE części Beskidu Sądeckiego w skali 1:25 000, przekroje geologiczne, profile litostratygraficzne, fotografie typowych litofacji wraz z objaśnieniami tekstowymi (in Polish). P.B.G "Geoprofil", Kraków.

Oszczypko, N., Oszczypko-Clowes, M., 2010b. The Paleogene and Early Neogene stratigraphy of the Beskid Sacdecki Range and Lubovnianska Vrchovina (Magura Nappe, Western Carpathians). Acta Geologica Polonica, 60: 317-348.

Oszczypko, N., Oszczypko-Clowes, M., 2014. Geological structure and evolution of the Pieniny Klippen Belt to the east of the Dunajec River - a new approach (Western Outer Carpathians, Poland). Geological Quarterly, 58 (4): 737-758.

Oszczypko, N., Andreyeva-Grigorovich, A., Malata, E. Oszczypko-Clowes, M., 1999. The Lower Miocene deposits of 
the Rača Sub-Unit near Nowy Sącz (Magura Nappe, Polish Outer Carpathians). Geologica Carpathica, 50: 419-433.

Oszczypko, N., Oszczypko-Clowes, M., Golonka, J., Marko, F., 2005a. Oligocene-Lower Miocene sequences of the Pieniny Klippen Belt and adjacent Magura Nappe between Jarabina and the Poprad River (East Slovakia and South Poland): their tectonic position and palaeogeographic implications. Geological Quarterly, 49 (4): 379-402.

Oszczypko, N., Oszczypko-Clowes, M., Golonka, J., Krobicki, M., 2005b. Position of the Marmarosh Flysch (Eastern Carpathians) and its relation to the Magura Nappe (Western Carpathians). Acta Geologica Hungarica, 48: 259-282.

Oszczypko-Clowes, M., 2001. The nannofossil biostratigraphy of the youngest deposits of the Magura Nappe (East of the Skawa river, Polish Flysch Carpathians) and their palaeoenviromental conditions. Annales Societatis Geologorum Poloniae, 71: 139-188.

Oszczypko-Clowes, M., 2012. Reworked nannofossils from the Lower Miocene deposits in Magura Nappe (Other Western Carpathians, Poland). Geologica Carpathica, 63: 407-424.

Oszczypko-Clowes, M., Sotak, J., Oszczypko, N., Surka, J., 2013. Biostratigraphic revision of the Magura Unit in the Horná Orava region (Slovakia): constraints for Oligomiocene formations. In: Geological evolution of the Western Carpathians: new ideas in the field of inter-regional correlations (eds. I. Broska and A. Tomašových): 66-67. GEEWEC Smolenice, Geological Institute, Slovak Academy of Sciences, 2013.

Paul, Z., Poprawa, D., 1992. Geology of the Magura Napppe in the Peri-Pieniny Zone in light of the Nowy Targ PIG 1 borehole. Przegląd Geologiczny, 40: 404-409.

Perch-Nielsen, K., 1985. Cenozoic calcareous nannofossils. In: Plankton Stratigraphy (eds. H. Bolli, J.S. Saunders and K. Perch-Nielsen): 427-554. Cambridge University Press.

Picha, F.J., Peters, K.E., 1998. Biomarker oil-to-source rock correlation in the Western Carpathians and their foreland, Czech Republic. Petroleum Geoscience, 4: 289-302.

Raciborski, M., 1892. Palaeobotanical notes (in Polish). Kosmos, 17: 526-533.

Raffi, I., Backman, J., Pälike, H., 2005. Nannofossil biohorizons of the Paleocene/Eocene transition at ODP Site 199-1215 in the paleo-equatorial Pacific Ocean. Palaeogeography, Palaeoclimatology, Palaeoecology, 226: 93-126.

Roth, P.H., 1973. Calcareous nannofossils: Leg 17, Deep Sea Drilling Project. Initial Reports DSDP, 17: 695.

Roth, P.H., Thierstein, H., 1972. Calcareous nannoplankton: Leg 14 of the Deep Sea Drilling Project. Initial Reports DSDP, 14: 421-485.
Rögl, F., Nagymarosy, A., 2004. Biostratigraphy and correlation of the Lower Miocene Michelstetten and Ernstbrunn sections in the Waschberg Unit, Austria (Upper Egerian to Eggenburgian, Central Paratethys). Courier Forschungsinstitut Senckenberg, 246: 129-151.

Schiller, J., 1930. Coccolithineae. Akademische Verlagsgesellschaft, Leipzig, 10: 89-267.

Shackleton, N.J., Hall, M.A., Raffi, I., Tauxe, L., Zachos, J., 2000. Astronomical calibration age for the Oligocene-Miocene boundary. Geology, 28: 447-450.

Siesser, W.G., 1993. Calcareous nannoplankton. In: Fossil Prokaryotes and Protists (ed. J.H. Lipps): 169-201. Blackwell Scientific Publications.

Szafer, W., 1946-1947. The Pliocene flora of Krościenko in Poland. I - General part - 1946, II - Descriptive part - 1947 (in Polish with English summary). Rozprawy Polskiej Akademii Umiejętności, 72.

Szafer, W., Oszast, J., 1964. The decline of Tertiary plants before the maximal glaciation of the West Carpathians. Reports of the Vlth International Congress on Quaternary: 479-482, Warszawa.

Uhlig V., 1890. Ergebnisse geologischer Aufnahmen in den westgalizischen Karpathen. Jahrbuch der Kaiserlich Königlichen Geologischen Reichsanstalt: 559-607, Wien, 1891.

Wallich, G.C., 1877. Observations on the coccosphere. Annals and Magazine of Natural History, 4: 322-339.

Watycha, L., 1976. The Neogene of the Orawa-Nowy Targ basin (in Polish with English summary). Kwartalnik Geologiczny, 20 (3): 575-585.

Watycha, L., 1977. Objaśnienia do szczegółowej mapy geologicznej Polski 1:50 000. Arkusz Czarny Dunajec (in Polish). Instytut Geologiczny, Warszawa.

Wei, W., Wise, S.W. Jr., 1990. Middle Eocene to Pleistocene calcareous nannofossils recovered by Ocean Drilling Program: Leg 113 in the Weddell Sea. Proceedings of the Ocean Drilling Program, Scientific Results, 113: 639-666.

Young, J., 1998. Miocene. In: Calcareous Nannofossil Biostratigraphy (ed. P. Bown): 225-265. Kluwer Academic Publishers, Dordrecht.

ytko, K., Zając, R., Gucik, S., Ryłko, W., Oszczypko, N., Garlicka, I., Nemčok, J., Eliáš, M., Menčik, E., Stránik, Z., 1989. Map of the tectonic elements of the Western Outer Carpathians and their foreland. In: Geological Atlas of the Western Outer Carpathians and their Foreland (eds. D. Poprawa and J. Nemčok). Państwowy Instytut Geologiczny, Warszawa/GUDŠ Bratislava/UUG Praha. 